\title{
Perancangan Sistem Kontrol Kelistrikan Otomatis Kompor Listrik Halogen Berbasis Mikrokontroler
}

\author{
Juliem Zulfadli ${ }^{1}$, Habibullah ${ }^{2}$ \\ 1,2Universitas Negeri Padang \\ Jl. Prof. Dr. Hamka, Air Tawar - Padang, Indonesia \\ juliemzulfadli@gmail.com ${ }^{1}$, habibullah@ft.unp.ac.id ${ }^{2}$
}

\begin{abstract}
The stove is one of the main tools used in households. Used to heat an object in the form of food. In its development, the stove used for cooking has experienced many advances, one of which is an electric stove. Currently electric stoves on the market, especially the electric stove, halogen heater, single ceramic stove, are available in the form of a rotary switch on / off. The purpose of writing this scientific research is to design an automatic control system on this single ceramic stove type halogen electric stove. Where previously stove control using only a rotary switch was changed to automatic control via a keypad in the form of a timer and temperature input with a digital display via LCD. The electrical components used are the Arduino Mega 2560 microcontroller as the control center, MAX6675 as a temperature sensor, ACS712 sensor to read current values, ZMPT101B sensor to read voltage values, relay as electric switch, buzzer as alarm, keypad as input and LCD as display output on electric stove. The results of this design were obtained in accordance with what was the goal of this scientific research where previously the electric stove was manually controlled to be converted into automatic control by inputting the required temperature value and working based on the temperature setpoint input and displaying the amount of energy released on the electric stove.
\end{abstract}

Keywords-Arduino Mega 2560, MAX6675, Relay, Halogen Electric Stove.

Abstrak - Kompor merupakan salah satu alat utama yang digunakan dalam rumah tangga. Digunakan untuk memanaskan suatu benda berupa makanan. Dalam perkembangannya kompor yang digunakan untuk memasak sudah mengalami banyak kemajuan, salah satunya adalah kompor listrik. Saat ini kompor listrik yang beredar di pasaran khususnya kompor listrik, pemanas halogen, kompor keramik tunggal, tersedia dalam bentuk tombol putar on / off. Tujuan penulisan penelitian ilmiah ini adalah merancang sistem kendali otomatis pada kompor listrik halogen jenis kompor keramik ini. Dimana sebelumnya pengendalian kompor yang hanya menggunakan sakelar putar diubah menjadi kontrol otomatis melalui keypad berupa pengatur waktu dan input suhu dengan tampilan digital melalui LCD. Komponen kelistrikan yang digunakan adalah mikrokontroler Arduino Mega 2560 sebagai pusat kendali, MAX6675 sebagai sensor suhu, sensor ACS712 untuk membaca nilai arus, sensor ZMPT101B untuk membaca nilai tegangan, relay sebagai sakelar listrik, buzzer sebagai alarm, keypad sebagai input dan LCD sebagai menampilkan output di kompor listrik. Hasil perancangan ini diperoleh sesuai dengan tujuan dari penelitian ilmiah ini dimana sebelumnya kompor listrik dikendalikan secara manual untuk diubah menjadi kontrol otomatis dengan menginput nilai temperatur yang dibutuhkan dan bekerja berdasarkan input setpoint temperatur dan menampilkan besarannya. energi yang dilepaskan di kompor listrik.

Kata kunci- Arduino Mega 2560, MAX6675, Relay, Kompor Listrik Halogen.

\section{Pendahuluan}

Peradaban manusia terus berkembang seiring dengan berjalannya waktu. Terdapat sebuah ungkapan yang mengatakan bahwa di dunia ini semuannya akan selalu berubah dan tidak ada yang tetap. Salah satu perubahan yang sangat nyata terjadi ditengah masyarakat ini adalah perubahan akan teknologi dan kebutuhan energi. Sudah menjadi rahasia umum bahwa seluruh umat manusia membutuhkan energi. Hal tersebut dapat dilihat dari seluruh aktifitas manusia yang ada seperti penerangan, memasak, komunikasi, dan lain-lainnya [1].

Dizaman sekarang, teknologi telah berkembang dengan begitu pesat. Dunia elektronika dan komputasi memiliki peranan yang sangat vital dalam teknologi dewasa ini. Saat ini ada begitu banyak perangkat elektronik yang dengan mudah dapat dijumpai dilingkungan masyarakat kini. Dengan hadirnya perangkat elektronik tersebut diharapkan mampu membantu pekerjaan manusia dengan lebih cepat, efisien, dan tentunnya dengan hasil yang lebih baik [2].

Makanan merupakan segala sesuatu yang dapat dikonsumsi oleh makhluk hidup berupa nutrisi yang berasal dari hewan dan tumbuhan yang sangat diperlukan oleh tubuh guna mendapatkan energi, pertumbuhan, pembentukan serta regenerasi jaringan tubuh guna proses keberlangsungan hidup[3]. Berdasarkan ketersediaanya makanan terbagi atas 2 jenis, yaitu makanan mentah dan makanan masak / makanan jadi. Untuk memperoleh makanan yang sehat, lezat, dan bergizi berupa makanan jadi, harus diperoleh dengan cara memasak makanan tersebut [4]. 
Memasak merupakan suatu kegiatan yang dapat menghasilkan sebuah makanan yang dapat merubah bahan makanan mentah menjadi matang dengan cara memanaskan bahan makanan mentah tersebut agar bisa dikonsumsi dan dapat memberikan cita rasa yang khas pada bahan makanan tersebut [5]. Untuk dapat memasak sebuah makanan, diperlukan kompor sebagai media untuk memasak makanan.

Kompor merupakan salah satu alat utama yang digunakan dirumah tangga. Kompor adalah alat yang digunakan untuk memanaskan suatu benda [6]. Di dalam rumah tangga, kompor merupakan alat memasak utama yang sangat dibutuhkan untuk keberlangsungan hidup. Selain untuk memasak makanan, alat ini juga digunakan untuk memasak minuman dan menghangatkan makanan yang sudah dimasak sebelumnya. Ditinjau dari kegiatan sehari-hari, penggunaan kompor dalam proses memasak sangatlah penting. Dalam perkembangannya kompor yang digunakan untuk memasak telah mengalami banyak kemajuan, dimana sebelumnya kompor hanya menggunakan bahan bakar berupa kayu bakar atau tungku kayu bakar, lalu berkembang ke minyak tanah kemudian dikonversi penggunaanya ke gas namun sekarang telah tersedia kompor dengan bahan bakar listrik.

Dalam perkembangannya, kompor yang digunakan sebagai alat untuk memasak makanan telah mengalami banyak kemajuan, salah satunya adalah kompor listrik. Saat ini kompor listrik yang beredar dipasaran, terutama kompor listrik heater halogen tipe single ceramic stove tersedia dalam bentuk kendali salklar putar on/off. Tujuan dari penulisan penelitian ilmiah ini adalah ingin merancang suatu sistem kontrol otomatis pada kompor listrik halogen tipe single ceramic stove ini. Dimana sebelumnya kendali kompor hanya menggunakan saklar putar dikembangkan pengontrolannya menjadi kendali otomatis melalui keypad berupa input timer dan suhu dengan tampilan digital melalui LCD. Komponen kelistrikan yang digunakan berupa mikrokontroler arduino mega 2560 sebagai pusat kontrol, MAX6675 sebagai sensor suhu, sensor ACS712 untuk membaca nilai arus, sensor ZMPT101B untuk membaca nilai tegangan, relay sebagai saklar listrik, buzzer sebagai alarm, keypad sebagai input dan LCD sebagai output tampilan pada kompor listrik. Diharapkan perancangan ini dapat mempermudah pekerjaan manusia dalam hal memasak makanan yang membutuhkan input suhu.

\section{Metode}

\section{Perancangan Mekanik}

Perancangan mekanik pada alat tugas akhir dibuat dengan menggunakan aplikasi software sketch up. Bentuk mekanik pada alat tugas akhir ini dapat dilihat pada gambar 1.

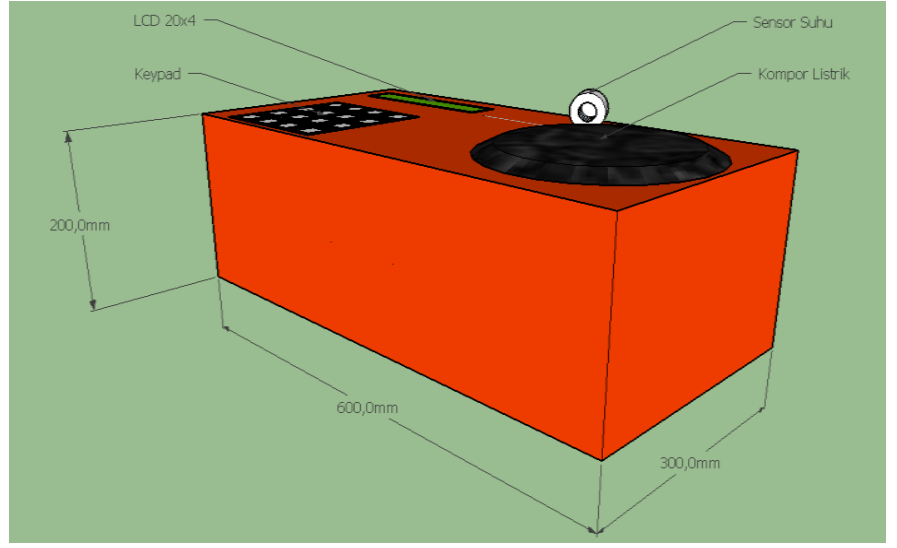

Gambar 1. Perancangan Mekanik Alat

\section{Perancangan Sistem Kontrol Kelistrikan}

Perancangan elektronik pada alat tugas akhir ini dibuat dengan menggunakan aplikasi software fritzing. Bentuk mekanik pada alat tugas akhir ini dapat dilihat pada gambar 2 .

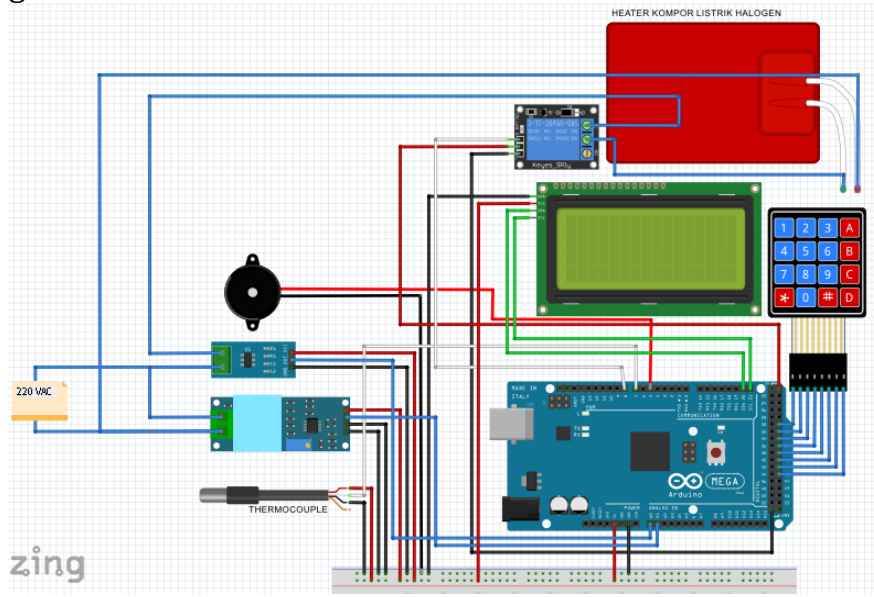

Gambar 2. Perancangan Elektronik Alat

\section{Blok Diagram}

Blok diagram merupakan salah satu bagian terpenting dalam perancangan ini. Dalam perancangan nya, alat terlebih dahulu dibuat suatu konsep agar lebih terlihat bentuk dan alur dari rancangan yang akan dibuat.

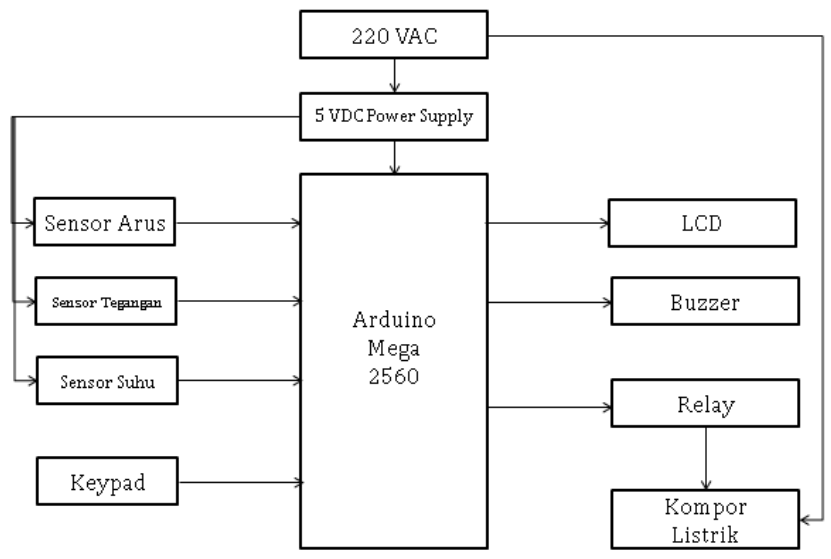

Gambar 3. Blok Diagram 
Pada blok diagram tersebut, disini akan dijelaskan komponen-komponen kelistrikan yang digunakan pada alat tugas akhir ini.

\section{Arduino Mega 2560}

Arduino Mega 2560 merupakan sebuah mikrokontroler dalam bentuk modul dimana perangkat kendali pada mikrokontrolernyo menggunakan chip Atmega 2560. Alasan digunakannya mikrokontroler Arduino Mega 2560 pada perancangan ini adalah karena modul ini memiliki kelebihan pada pin input output dan digitalnya yang sebanyak 54 buah pin i/o. Dimana 14 buah pin digunakan untuk PWM output, 16 buah pin digunakan sebagai analog input, 4 buah pin untuk UART, $16 \mathrm{MHz}$ osilator kristal, dan koneksi USB atau listrik dengan adaptor dari AC ke DC atau baterai untuk pemakaian. Selain itu, kelebihan lain yang terdapat pada arduino jenis ini adalah dilengkapi dengan USB Current Protection dibandingkan dengan arduino jenis lain[7].

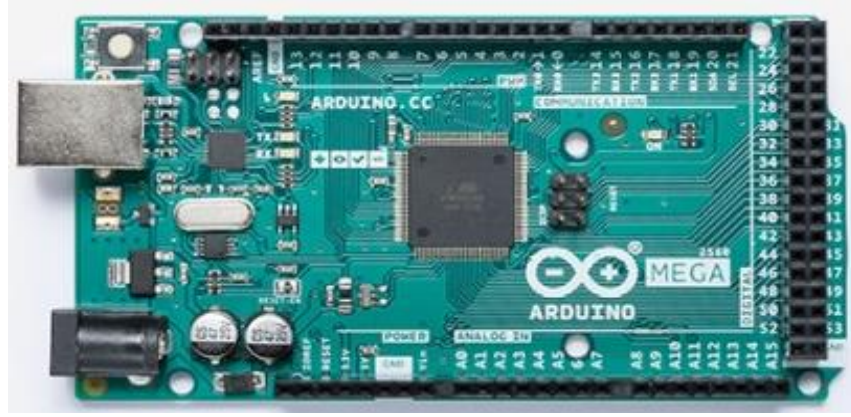

Gambar 4. Arduino Mega 2560

\section{Sensor Arus}

Sensor arus yang digunakan pada perancangan ini adalah sensor arus ACS712. Kelebihan dari penggunaan jenis sensor ini adalah sensor ini mampu membaca arus hingga $30 \mathrm{~A}$ dengan batas tegangan tertinggi sebesar 300 VAC [8]. Sensor arus ACS712 digunakan untuk membaca nilai arus listrik yang mengalir pada perancangan kompor listrik halogen.

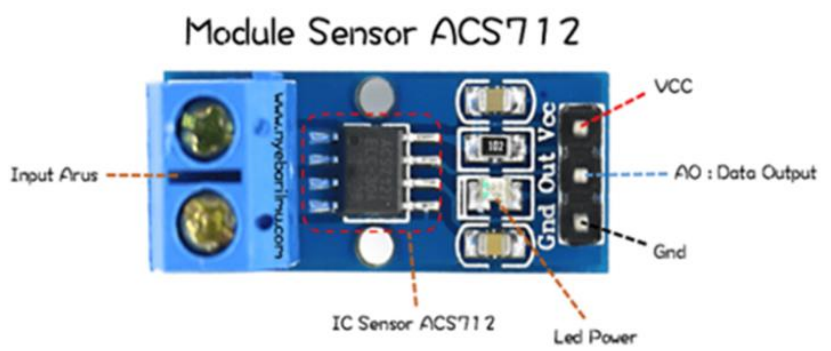

Gambar 5. ACS712

\section{Sensor Tegangan}

Sensor tegangan yang digunakan pada perancangan ini adalah sensor tegangan ZMPT101B. Kelebihan dari penggunaan jenis sensor ini adalah sensor ini mampu mengkonversi nilai tegangan ac yang diperoleh sebesar
220 VAC menjadi 5 VDC tegangan arduino yang nilainya ditampilkan secara digital melalui LCD [9]. Sensor tegangan ZMPT101B digunakan untuk membaca nilai tegangan listrik yang mengalir ke beban berupa kompor listrik halogen.

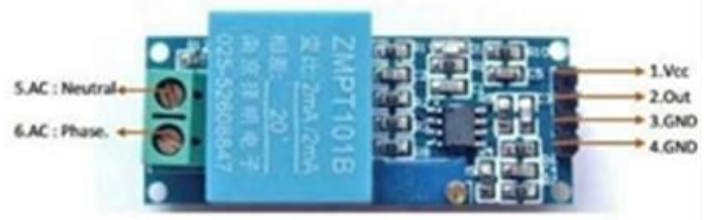

Gambar 6. ZMPT101B

\section{Sensor Suhu}

Sensor suhu yang digunakan pada perancangan ini adalah sensor suhu MAX6675 atau yang lebih dikenal dengan thermocouple type K. Kelebihan dari penggunaan jenis sensor ini adalah sensor ini memiliki kelebihan dibandingkan dengan sensor termokopel tipe lainnya, seperti material yang digunakan berupa gabungan antara nickel-chrominium dan nickel-alumuniun serta tingkat akurasi pengukuran suhu yang baik dengan rentang suhu 200 derajat celcius hingga 1250 derajat celcius [10].

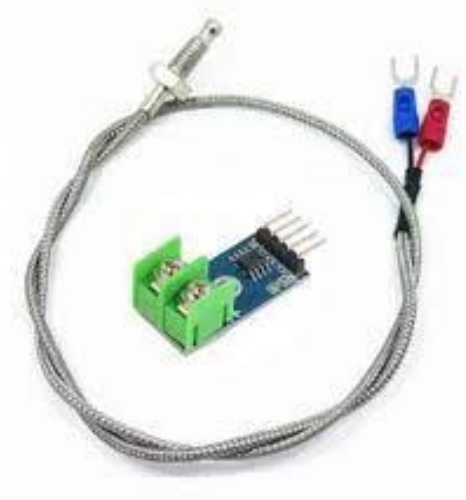

Gambar 7. Thermocouple

\section{Keypad}

Keypad merupakan sebuah miniature keyboard atau set tombol yang digunakan untuk tujuan operasi pada portable, input pada peralatan elektronik, dan peralatan lainnya yang membutuhkan perintah masukan. Keypad adalah bagian penting dari suatu perangkat elektronika yang membutuhkan interaksi dengan manusia. Keypad berfungsi sebagai interface antara perangkat (mesin) elektronik dengan manusia atau dikenal dengan istilah HMI (Human Machine Interface). Fungsi keypad pada perancangan ini adalah sebagai input berupa suhu, perintah berupa menu pilihan dan timer. 


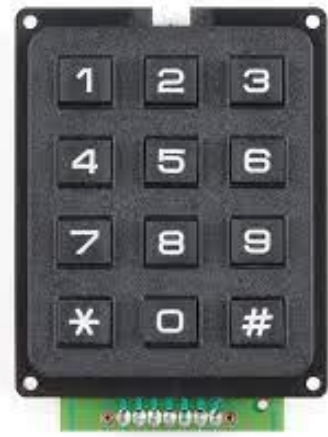

Gambar 8. Keypad

\section{LCD}

Liquid Crystal Display adalah sebuah komponen elektronika yang digunakan untuk menampilkan suatu karakter, baik itu angka, huruf atau karakter tertentu, sehingga tampilan tersebut dapat dilihat secara visual. LCD banyak digunakan sebagai display dari alat-alat elektronik seperti kalkulator, multitester digital, jam digital dan sebaginya. LCD pada rancangan ini berfungsi sebagai output berupa tampilan digital nilai dari penggunaan alat berupa timer, nilai tegangan, nilai arus, dan nilai suhu.

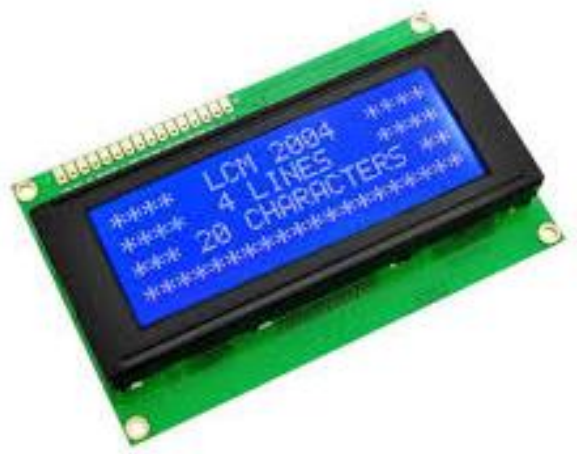

Gambar 9. Liquid Crystal Display

\section{Buzzer}

Buzzer merupakan sebuah komponen elektronika yang masuk ke dalam keluarga transducer, berfungsi untuk mengubah sinyal listrik menjadi getaran suara. Nama lain dari komponen ini adalah beeper. Jenis-jenis dari buzzer yang sering ditemui dipasaran yaitu tipe piezoelectric. Hal tersebut dikarenakan tipe ini memiliki kelebihan seperti harganya yang relative murah dan mudah diaplikasikan ke dalam rangkaian elektronika.

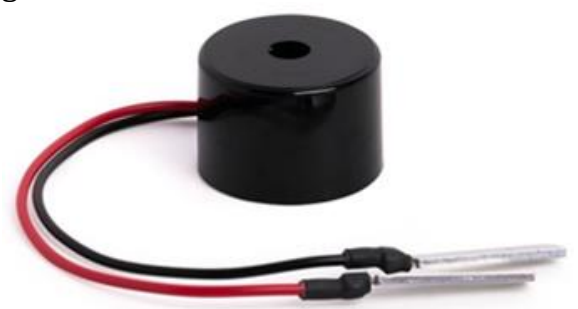

Gambar 10. Buzzer

\section{Relay}

Relay merupakan suatu komponen elektronika yang berfungsi sebagai saklar elektronik yang digerakkan oleh arus listrik. Relay bekerja secara otomatis dengan cara memberikan tegangan pada koil. Alat ini dapat berkeja dengan memanfaatkan gaya magnet dari koil yang terdapat dalam relay karena diberikan tegangan listrik. Relay banyak digunakan pada beberapa rangkaian elektronika misalnya pada pengaplikasian saklar otomatis dengan sumber tegangan $220 \mathrm{AC}$.

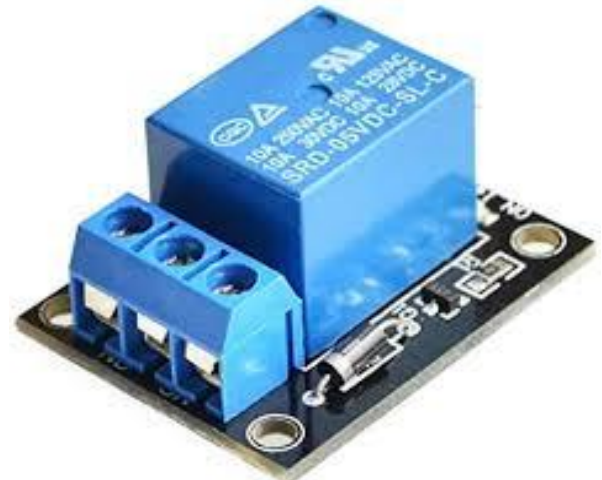

Gambar 11. Relay

\section{Kompor Listrik}

Kompor listrik adalah salah satu peralatan elektronik rumah tangga yang berfungsi untuk memasak dan memanaskan makanan dengan sumber energi listrik. Kompor listrik yang digunakan pada perancangan tugas akhir ini adalah kompor listrik halogen tipe single ceramic stove. Tegangan kerja pada kompor listrik sebesar 220 VAC - 250 VAC dengan daya listrik 1000 watt.

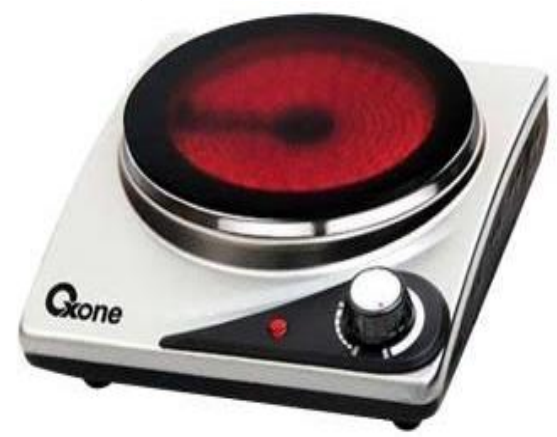

Gambar 12. Kompor Listrik Halogen

\section{Perancangan Software}

Perangkat lunak yang digunakan pada pembuatan program ini adalah Arduino-IDE. Arduino-IDE merupakan sebuah perangkat lunak yang digunakan untuk pemograman mikrokontroler Arduino dengan menggunakan bahasa C [11]. Untuk pemograman dengan menggunakan software Arduino-IDE, download terlebih dahulu software Arduino-IDE. Ekstraks file yang didownload jika bentuk format dari file yang didownload tersebut adalah .rar. Kemudian install software ArduinoIDE. Software dari Arduino-IDE ini bersifat open source, tersedia untuk para pemogram pemula maupun 
berpengalaman untuk dapat mengembangkan Bahasa pemogramannya. Untuk Bahasa yang digunakan pada software ini adalah Bahasa $\mathrm{C}$ yang disederhanakan dalam bentuk library Arduino. Untuk merancang sebuah program dan menjalankannya, dimulai dengan mendesainnya dalam bentuk flowchart sistem dari program yang akan dibuat.

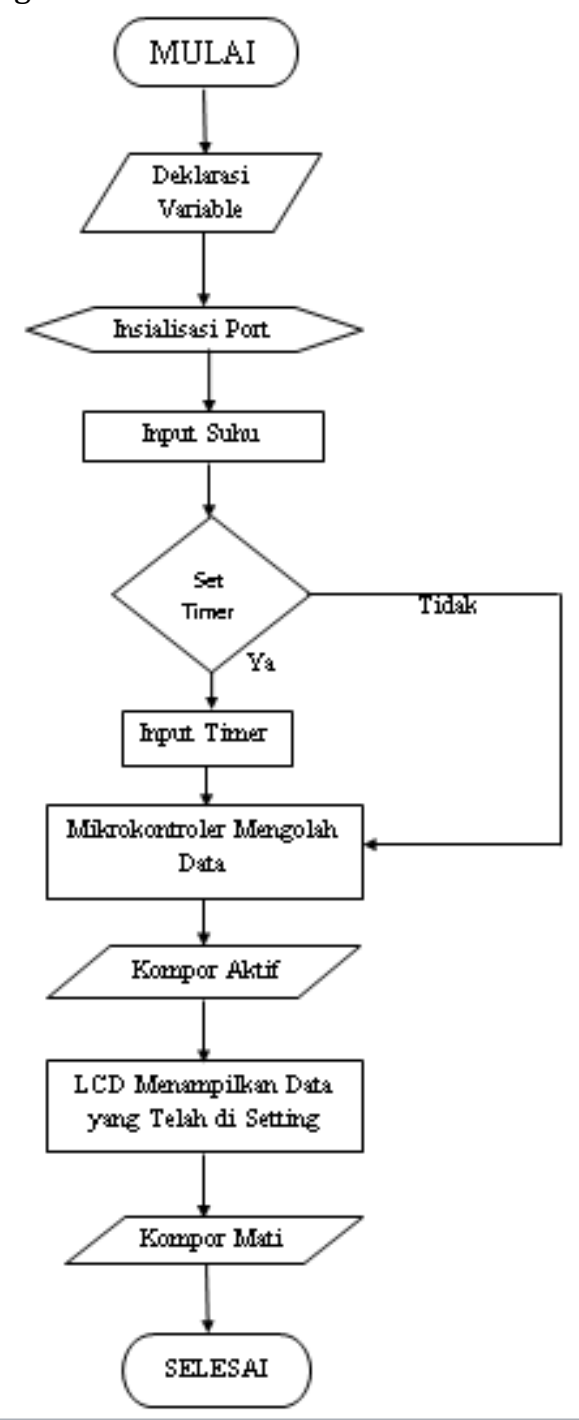

Gambar 13. Flowchart Sistem Kerja Alat

Diagram alir atau yang lebih dikenal dengan Flowchart merupakan suatu metode yang digunakan untuk menggambarkan aliran proses dari suatu operasi. Berdasarkan sifatnya, diagram ini sangat cocok diimplementasikan dengan memanfaatkan algoritma yang ditulis pada computer. Flowchart dapat digunakan untuk menggambarkan ide ke dalam bentuk simbol-simbol agar mudah dipahami. Diagram alir (Flowchart) merupakan sebuah alur yang dituangkan ke dalam bentuk gambar/simbol. Flowchart menolong programmer untuk memecahkan masalah kedalam segmen-segmen yang lebih kecil dalam pengoperasiannya. Simbol-simbol flowchart yang biasanya dipakai adalah simbol-simbol flowchart standar yang dikeluarkan oleh ANSI dan ISO.

Dari flowchart diatas, dapat dijelaskan bahwa pada saat alat diaktifkan, program yang telah diupload ke mikrokontroller mulai mendeklarasikan variable berupa program dan mulai menginisiasi port menuju pin inputoutput yang telah ditentukan oleh program sebelumnya. Saat alat aktif, LCD menyala dan mulai menampilkan output berupa perintah untuk menginputkan nilai suhu yang dibutuhkan melalui keypad. Setelah menginputkan nilai suhu, selanjutnya masuk ke menu set timer. Jika memilih opsi ya, maka inputkan nilai timer waktu yang dibutuhkan. Jika memilih opsi tidak, maka mikrokontroler mengolah data yang diinputkan, dan kemudian kompor aktif. Disaat kompor aktif, LCD sebagai output menampilkan data yang telah disetting pada program yang dibuat, seperti menampilkan nilai tegangan, nilai arus, nilai suhu, dan tampilan waktu berupa set timer. Setelah selesai memasak, maka kompor listrik akan mati. Ada dua cara yang dapat dilakukan untuk dapat mematikan kompor listrik. Cara yang pertama yaitu dengan menekan tombol stop yang tersedia pada. Lalu yang kedua dengan cara jika menggunakan set timer, maka kompor listrik akan mati dengan sendirinya sesuai dengan timer yang telah diinputkan sebelumnya.

\section{HASIL DAN PEMBAHASAN}

Pada bagian hasil dan pembahasan perancangan tugas akhir ini lebih difokuskan pada kinerja kompor listrik yan dirancang. Pengujian mekanik ini bertujuan untuk membandingkan hasil dari perancangan mekanik yang telah dirancang sebelumnya dengan hasil jadi pembuatan. Pada perancangan otomatis ini menggunakan mikrokontroller Arduino Mega 2560, untuk pengontrolan sistem keseluruhan serta menggunakan komponenkomponen kelistrikan seperti sensor arus, sensor tegangan, sensor thermocouple, keypad 4x4, LCD 20x4, Module Relay dan buzzer. Kompor listrik halogen ini tersusun dari rangka dan selimut luar yang terbuat dari alumunium, serta bagian bawah yang terdiri dari 2 lapisan, yaitu lapisan atas (pertama) yang terbuat dari triplek berfungsi sebagai kedudukan komponen listrik dan lapisan bawah terbuat dari alumunium yang berfungsi sebagai alas. Alat ini berbentuk persegi panjang dengan dimensi $60 \mathrm{~cm} \mathrm{x} 30 \mathrm{~cm} \times 10 \mathrm{~cm}$. 


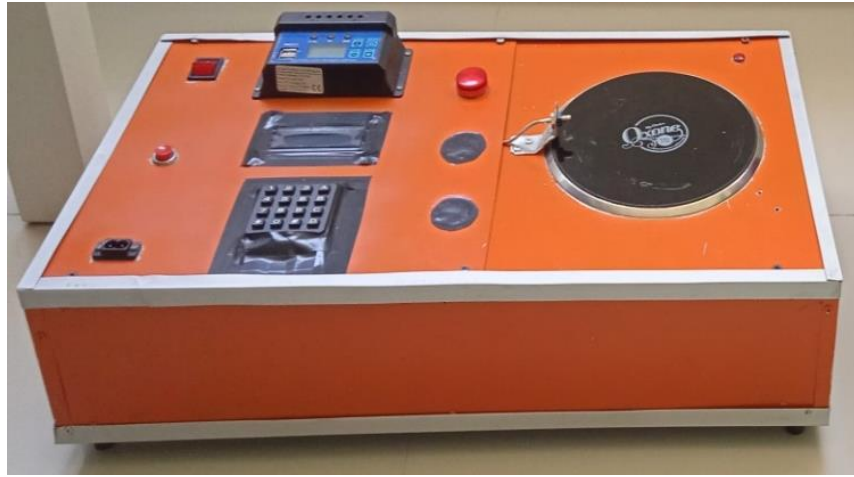

Gambar 14. Bentuk Mekanik Alat

Kompor listrik yang digunakan pada pengujian ini adalah kompor listrik halogen tipe single ceramic stove. Pada hasil pengujian difokuskan untuk mengetahui kinerja dari kompor listrik ini, berapa lama waktu yang dibutuhkan untuk merebus 1 liter air pada suhu titik didih sebesar 100 derajat celcius, berapa kenaikan suhu yang terjadi setiap waktunya, berapa selisih yang dihasilkan dan perbandingan hasil pengukuran dengan menggunakan alat ukur thermogun.

Tabel 1. Hasil Pengujian Kompor Listrik dengan Kompor Gas

\begin{tabular}{ccc}
\hline \multirow{2}{*}{ PENGUJIAN } & \multicolumn{2}{c}{ WAKTU } \\
\cline { 2 - 3 } & KOMPOR GAS & KOMPOR LISTRIK \\
\hline 1 & 17 menit 7detik & 11menit \\
\hline 2 & 17 menit 14detik & 11menit 5detik \\
\hline 3 & 17 menit 17detik & 11menit 11detik \\
\hline
\end{tabular}

Data diatas merupakan hasil pengujian berupa berapa lama waktu yang dibutuhkan untuk mendidihkan air sebesar 1 liter pada suhu 100 derajat celcius. Pengujian dilakukan sebanyak tiga kali untuk mendapatkan nilai yang sebenarnya. Dari pengujian diatas, waktu yang diperlukan oleh kompor gas lebih kurang selama 17 menit. Sedangkan waktu yang diperlukan pada alat kompor listrik ini kurang lebih selama 11 menit. Selisih waktu yang dihasilkan keduanya kurang lebih selama 6 menit. Dapat disimpulkan bahwa alat kompor listrik ini lebih unggul dan efisiensi waktu dibandingkan dengan kompor gas.

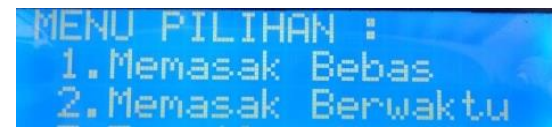

Gambar 15. Opsi Kontrol pada Kompor Listrik

Dari gambar diatas, dapat dilihat bahwa pada perancangan kompor listrik ini digunakan 2 opsi pengontrolan, yaitu opsi memasak bebas dan opsi memasak berwaktu. Pada opsi pertama yaitu memasak bebas, dimana pada opsi ini hanya menginputkan set point berupa nilai suhu yang dibutuhkan. Ketika alat aktif, sensor suhu membaca nilai suhu yang terdapat pada beban. Saat sensor suhu membaca nilai suhu melebihi set point yang telah diinputkan sebelumya, relay sebagai saklar listrik memutus aliran listrik dari sumber ke kompor listrik. Kompor listrik dalam kondisi off dan suhu mulai menurun atau melakukan penyesuaian nilai dengan nilai input setpoint. Disaat sensor suhu membaca nilai suhu dibawah nilai set point yang telah diinputkan sebelumnya, maka relay aktif dan menghubungkan arus listrik dari sumber ke kompor listrik. Kompor listrik dalam kondisi on dan suhu mulai naik atau melakukan penyesuaian nilai dengan input setpoint suhu. Hal tersebut akan terjadi secara kontinyu atau terus menerus selama alat terhubung ke sumber listrik. Untuk menghentikannya dapat dengan menggunakan 2 cara. Cara yang pertama yaitu dengan menekan tombol D pada keypad. Atau dengan cara kedua yaitu dengan menekan tombol reset yang terdapat dikompor.

Pada pengujian pertama adalah merebus 1 liter air dengan input setpoint suhu sebesar 100 derajat celcius. Tujuan dari pengujian ini adalah untuk mengetahui berapa lama waktu yang diperlukan, apakah dengan input setpoint sebesar 100 derajat tersebut tercapai juga suhu sebesar 100 derajat celcius melalui alat ukur thermogun, serta berapa selisih dan persentase kesalahan pengukuran yang dihasilkan antara hasil pengukuran dengan sensor thermocouple dengan pembacaan dari alat ukur thermogun. Opsi kontrol pilihan memasak yang digunakan adalah opsi memasak bebas.

\begin{tabular}{|c|c|c|c|c|c|}
\hline No & $\begin{array}{l}\text { WAKTU } \\
\text { (J:M:D) }\end{array}$ & $\begin{array}{c}\text { SUHU } \\
\text { THERMOCOUPLE }\end{array}$ & $\begin{array}{c}\text { SUHU } \\
\text { THERMOGUN }\end{array}$ & $\begin{array}{l}\text { LOGIC } \\
\text { RELAY }\end{array}$ & $\begin{array}{l}\text { KONDISI } \\
\text { KOMPOR }\end{array}$ \\
\hline 1 & 00.00 .03 & 28,5 & 25,6 & $\mathrm{HIGH}$ & $\mathrm{ON}$ \\
\hline 2 & 00.01 .00 & 32,7 & 30,4 & $\mathrm{HIGH}$ & $\mathrm{ON}$ \\
\hline 3 & 00.02 .00 & 39,0 & 36,0 & HIGH & $\mathrm{ON}$ \\
\hline 4 & 00.03 .00 & 47,7 & 44,6 & $\mathrm{HIGH}$ & $\mathrm{ON}$ \\
\hline 5 & 00.04 .01 & 57,0 & 53,3 & HIGH & $\mathrm{ON}$ \\
\hline 6 & 00.05 .04 & 66,5 & 61,4 & $\mathrm{HIGH}$ & $\mathrm{ON}$ \\
\hline 7 & 00.06 .00 & 71,7 & 67,2 & HIGH & ON \\
\hline 8 & 00.07 .00 & 77,5 & 77,8 & HIGH & $\mathrm{ON}$ \\
\hline 9 & 00.08 .00 & 83,2 & 86,6 & HIGH & $\mathrm{ON}$ \\
\hline 10 & 00.09 .00 & 88,2 & 90,5 & $\mathrm{HIGH}$ & ON \\
\hline 11 & 00.10 .00 & 93,5 & 95,6 & HIGH & ON \\
\hline 12 & 00.11 .00 & 100,2 & 98,8 & LOW & OFF \\
\hline 13 & 00.12 .00 & 100,5 & 97,1 & LOW & OFF \\
\hline 14 & 00.13 .00 & 101,1 & 95,4 & LOW & OFF \\
\hline 15 & 00.14 .00 & 100,9 & 92,3 & LOW & OFF \\
\hline 16 & 00.15 .00 & 100,7 & 89,2 & LOW & OFF \\
\hline 17 & 00.16 .00 & 100,4 & 87,7 & LOW & OFF \\
\hline 18 & 00.17 .00 & 100,1 & 85,2 & LOW & OFF \\
\hline 19 & 00.18 .00 & 99,1 & 86,6 & HIGH & $\mathrm{ON}$ \\
\hline
\end{tabular}




\begin{tabular}{llllll}
\hline 20 & 00.19 .00 & 98,9 & 87,4 & HIGH & ON \\
\hline 21 & 00.20 .00 & 99,0 & 88,1 & HIGH & ON \\
\hline 22 & 00.21 .00 & 99,5 & 89,3 & HIGH & ON \\
\hline 23 & 00.22 .00 & 99,8 & 91,7 & HIGH & ON \\
\hline 24 & 00.23 .00 & 100,0 & 94,5 & LOW & OFF \\
\hline
\end{tabular}

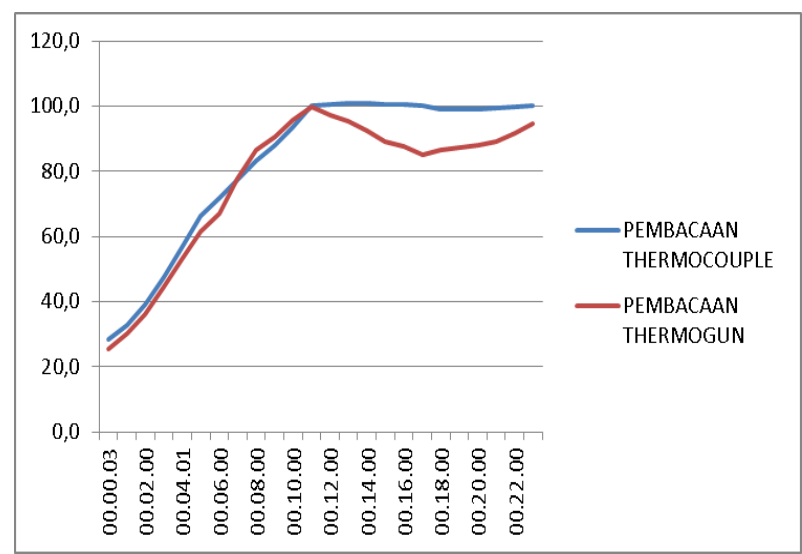

Gambar 16. Grafik Perbandingan Kenaikan Suhu

Dari hasil pengujian memasak bebas diatas yang ditampilkan dalam bentuk tabel dan grafik, dapat disimpulkan bahwa waktu yang dibutuhkan untuk merebus 1 liter air dengan input set point suhu sebesar 100 derajat celcius dibutuhkan waktu selama 11 menit. Termokopel sebagai sensor suhu membaca nilai suhu pada alat masak. Setelah mencapai nilai setpoint input suhu, relay sebagai saklar listrik memutus arus listrik ke beban sehingga kondisi kompor off/mati. Pembacaan nilai suhu pada termokopel mengalami fluktuasi/naik-turun nilai suhu, namun pada pembacaan alat ukur nilai suhu mengalami penurunan yang cukup signifikan selama kompor dalam kondisi off. Hal tersebut disebabkan karena posisi sensor suhu yang membaca nilai suhu pada alat masak makanan, sementara alat ukur membaca nilai suhu pada objek beban/masakan itu sendiri. Setelah sensor suhu membaca nilai suhu kurang dari nilai setpoint input suhu, relay aktif dan kompor dalam kondisi on. Hal tersebut berlangsung secara terus menerus selama kompor terhubung ke sumber listrik. Untuk menghentikannya cukup dengan menekan tombol off yang terdapat pada kompor listrik. Selisih pembacaan nilai suhu yang dihasilkan antara sensor suhu thermocouple dengan thermogun sebagai alat ukur cukup besar. Hal tersebut dapat dilihat pada tampilan grafik perbandingan kenaikan suhu yang terjadi antara sensor dengan alat ukur.

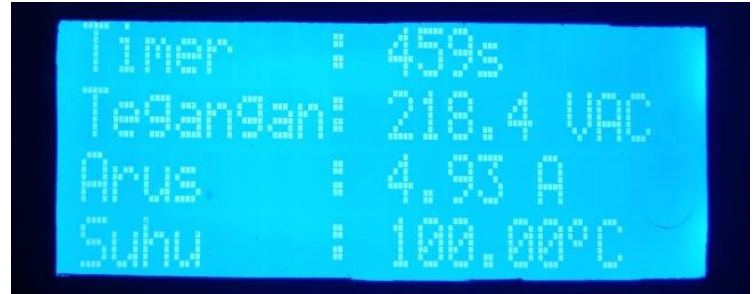

Gambar 17. Tampilan Opsi Memasak Bebas

Pada opsi kedua yaitu opsi memasak berwaktu, dibutuhkan dua kali penginputan setpoint pada keypad. Input pertama yaitu input setpoint suhu yabg dibutuhkan untuk memasak. Input kedua yaitu input set timer berupa waktu yang dibutuhkan untuk memasak. Disaat alat aktif, thermocouple membaca nilai suhu yang terdapat pada beban. Saat sensor suhu membaca nilai suhu melebihi setpoint yang telah diinputkan sebelumnya, relay sebagai saklar listrik memutus aliran listrik dari sumber ke kompor listrik. Kompor listrik dalam kondisi off, suhu mulai menurun dan melakukan penyesuaian nilai dengan nilai input set point. Disaat thermokopel membaca nilai suhu dibawah nilai set point yang telah diinputkan sebelumnya, maka relay aktif dan menghubungkan arus listrik dari sumber ke kompor listrik. Kompor listrik dalam kondisi on dan suhu mulai naik atau melakukan penyesuaian nilai dengan input setpoint suhu. Hal tersebut akan terjadi secara kontinyu atau terus menerus hingga timer waktu berakhir. Saat timer waktu berakhir, relay sebagai saklar listrik memutus aliran arus dari sumber ke beban. Kompor listrik dalam kondisi off. LCD yang sebelumya menampilkan nilai suhu, tegangan, arus dan timer kembali ke tampilan awal menu pilihan.

\begin{tabular}{|c|c|c|c|c|c|}
\hline NO & $\begin{array}{l}\text { REAL } \\
\text { TIME }\end{array}$ & $\begin{array}{c}\text { PEMBACAAN } \\
\text { THERMOCOUPLE }\end{array}$ & $\begin{array}{l}\text { PEMBACAAN } \\
\text { THERMOGUN }\end{array}$ & $\begin{array}{l}\text { LOGIC } \\
\text { RELAY }\end{array}$ & $\begin{array}{l}\text { KONDISI } \\
\text { KOMPOR }\end{array}$ \\
\hline 1 & 00.00 .00 & 28,5 & 25,8 & HIGH & $\mathrm{ON}$ \\
\hline 2 & 00.01 .00 & 31,7 & 30,8 & HIGH & ON \\
\hline 3 & 00.02 .00 & 38,5 & 39,0 & HIGH & ON \\
\hline 4 & 00.03 .00 & 48,5 & 51,0 & HIGH & ON \\
\hline 5 & 00.04 .00 & 57,7 & 62,0 & HIGH & ON \\
\hline 6 & 00.05 .00 & 68,5 & 69,9 & HIGH & ON \\
\hline 7 & 00.06 .00 & 77,0 & 79,0 & HIGH & ON \\
\hline 8 & 00.07 .00 & 82,7 & 84,0 & HIGH & ON \\
\hline 9 & 00.08 .00 & 87,7 & 88,0 & HIGH & ON \\
\hline 10 & 00.09 .00 & 94,0 & 92,3 & HIGH & ON \\
\hline 11 & 00.10 .00 & 99,0 & 96,6 & HIGH & $\mathrm{ON}$ \\
\hline 12 & 00.10 .19 & 100,5 & 100,0 & LOW & OFF \\
\hline 13 & 00.10 .22 & 100,7 & 99,8 & LOW & OFF \\
\hline 14 & 00.10 .25 & 100,7 & 99,5 & LOW & OFF \\
\hline 15 & 00.11 .05 & 101,0 & 97,7 & LOW & OFF \\
\hline
\end{tabular}




\begin{tabular}{cccccc}
\hline 16 & 00.11 .57 & 100,2 & 96,3 & LOW & OFF \\
\hline 17 & 00.13 .00 & 100,7 & 95,8 & LOW & OFF \\
\hline 18 & 00.14 .05 & 99,3 & 94,4 & HIGH & ON \\
\hline 19 & 00.14 .30 & 99,0 & 95,6 & HIGH & ON \\
\hline 20 & 00.14 .55 & 99,7 & 96,6 & HIGH & ON \\
\hline
\end{tabular}

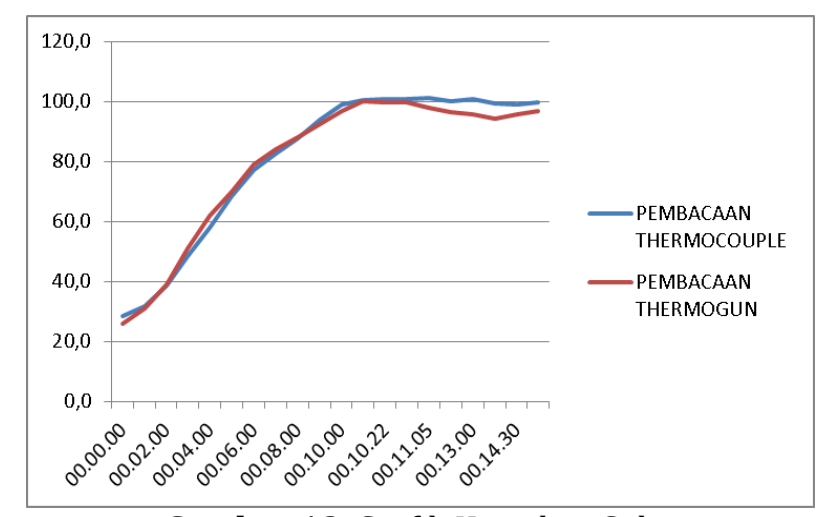

Gambar 18. Grafik Kenaikan Suhu

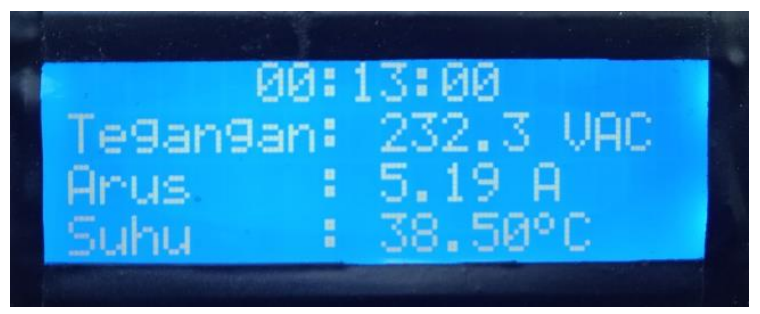

Gambar 19. Tampilan Opsi Memasak Berwaktu

Dari hasil pengujian memasak berwaktu diatas yang ditampilkan dalam bentuk tabel dan grafik, dapat dianalisa bahwa waktu yang dibutuhkan untuk merebus 1 liter air dengan input set point suhu sebesar 100 derajat celcius dibutuhkan waktu selama kurang lebih 10 menit. Pada opsi memasak berwaktu ini, nilai waktu/timer yang diinputkan selama 15 menit. Setelah suhu yang terbaca oleh sensor mendeteksi nilai suhu melebihi input setpoint, relay yang berfungsi sebagai sakalr elektrik memutus aliran arus listrik dari sumber ke koompor. Kondisi kompor off dengan logic relay low. Saat sensor termokopel membaca nilai suhu kurang dari setpoint, relay aktif kompor listrik hidup dan sensor suhu melakukan penyesuaian nilai suhu yang diperoleh. Sistem akan selesai setelah set timer waktu habis dan tampilan pada LCD kembali ke menu utama. Selisih pembacaan yang dihasilkan antara sensor suhu thermocouple dengan thermogun sebagai alat ukur pada pengujian kali ini cukup stabil dengan selisih nilai yang dihasilkan cukup kecil. Untuk tampilan grafik perbandingan kenaikan suhu yang terjadi antara sensor dengan alat ukur kenaikan suhu yang terjadi antar keduanya cukup stabil. Setelah mencapai suhu yang telah ditentukan, kompor listrik mati dan suhu pada beban mengalami penurunan. Hal tersebut dapat dilihat pada pembacaan suhu pada alat ukur thermogun yang mengalami penurunan serta mengalami kenaikan suhu pada saat kompor listrik menyala. Kompor akan benar-benar mati atau dalam kondisi off apabila sudah mencapai nilai timer waktu yang diinputkan sebelumnya.

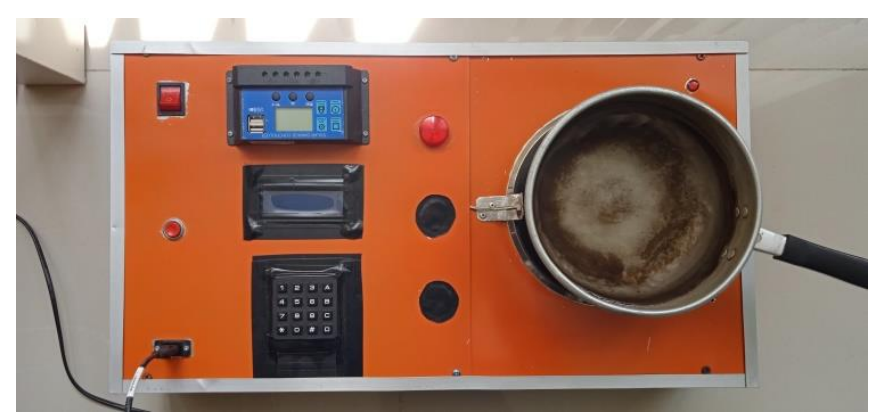

Gambar 20. Pengujian dengan 1 Liter Air

Prinsip kerja dari alat ini berdasarkan input dari setpoint nilai suhu melalui keypad. Jika sensor suhu membaca nilai suhu kurang dari nilai input setpoint, maka relay aktif dan kompor dalam kondisi menyala. Dan jika sensor suhu membaca nilai suhu lebih dari nilai setpoint yang telah diinputkan sebelumnya, maka logic relay dalam kondisi low dan kompor dalam kondisi off. Untuk opsi memasak bebas proses on/off kompor berlangsung secara kontinyu selama kompor terhubung ke sumber listrik. Sedangkan untuk opsi memasak berwaktu, kompor bebanbenar off bila sudah mencapai waktu input timer yang telah ditentukan sebelumnya.

Untuk nilai data yang diperoleh pada saat pengujian dan pengambilan data, baik itu waktu yang diperlukan untuk memanaskan suatu objek, selisih suhu, dan persentase error yang diperoleh, baik itu memasak bebas maupun berwaktu bersifat fluktuatif. Hal tersebut disebabkan oleh usia dan tingkat intensitas pemakaian hot junction termokopel ke beban, posisi sensor suhu, jarak ujung sensor suhu (hot junction) yang harus menyentuh langsung secara keseluruhan dengan beban, jenis dan ketebalan alat masak yang digunakan. Dimana semakin tebal jenis dan bahan alat masak yang digunakan, maka selisih nilai suhu yang diperoleh dengan yang terukur juga semakin besar.

\section{Penutup}

Berdasarkan perancangan alat yang telah dikerjakan, pengujian yang telah dilakukan, dan data yang telah diperoleh selama melaksanakan penelitian alat tugas akhir ini, maka dapat disimpulkan bahwa hasil dari pengujian kompor listrik halogen ini, untuk mendidihkan air sebanyak 1 liter di suhu 100 derajat celcius, diperlukan waktu selama lebih kurang 11 menit. Setelah mencapai suhu yang ditentukan, relay sebagai saklar listrik memutus arus listrik ke beban sehingga kompor listrik dalam kondisi off. Sensor thermocouple sebagai sensor suhu berfungsi untuk membaca nilai suhu pada beban dan 
melakukan penyesuaian. Jika suhu pada beban dibawah set point suhu yang telah diinputkan sebelumya, maka relay sebagai saklar listrik menghubungkan arus listrik ke beban sehingga kompor listrik dalam kondisi on dan sensor suhu melakukan penyesuaian suhu pada beban dengan set point suhu yang telah diinputkan sebelumnya. Untuk sistem kelistrikan dan komponen-komponen yang terdapat didalamnya bekerja dengan baik walaupun terdapat beberapa nilai error/kesalahan yang dapat ditoleransi oleh sensor sehingga tidak mengganggu kinerja alat.

\section{REFERENSI}

[1] Arifin, Fatahul. "Desain dan Prototype Kompor Tenaga Surya dengan Sistem Reflektor Tunggal." Palembang : Politeknik Negeri Sriwijaya, vol. 1, pp. 1-10, Sep. 2018.

[2] Yuliza, Hasan Panggaribuan. "Rancang Bangun Kompor Listrik dengan Digital IOT." Jakarta : Universitas Mercubuana, vol. 1, pp. 1-6, Sep 2016.

[3] Angga, Irawan. 2018. Desain Aplikasi Sel Surya dan Kompor Listrik untuk Pedagang Kaki Lima. Surakarta : Universitas Muhammadiyah Surakarta.

[4] Farhan, Muharrom." Rancang Bangun Alat Pendeteksi Logam pada Makanan". Padang : Universitas Negeri Padang, 2016.

[5] Ervinasari, Maya. "Rancang Bangun Kompor Listrik dengan Perintah Suara". Surabaya : Universitas Hangtuah Surabaya, no. 1, vol. 2, pp. 1-5, Mar 2018.

[6] Wardana, Heru. "Rancang Bangun Kompor Listrik Tenaga Surya”. Batam : Politeknik Negeri Batam, no. 2, vol. 2, pp. 1-11, 2014.

[7] (2017) The Arduino Website. [Online]. Getting Started with Arduino Mega 2560. Available https://www.arduino.cc/en/Guide/ArduinoMega2 560 . Access July 2020.

[8] “ACS712 Data Sheet", Allegro MicroSystem, Massachusetts, U.S.A.

[9] Abidin, Zaenal and Bahaudin, "Monitoring dan Proteksi Tegangan Panel 3 Phase dengan Menggunakan Sensor Tegangan ZMPT101B", vol. 1, pp. 1-8, 2018.

[10] Syufrawardi, Yohandri and Arizal. "Sistem Pengontrolan Temperature ON-OFF menggunakan Mikrokontroler dan Pengindraan Thermocouple". SAINSTEK vol. IX, no. 1, Sep 2008.

[11] Rachmat, Antonius. Algoritma dan Pemograman dengan Bahasa C. Yogyakarta : Andi, 2010.

[12] J. Sardi, M. Iqbal, A. B. Pulungan, and Habibullah, "Pemograman Alat Penimbang dan Packing Beras Berbasis Mikrokontroler," JTEV (Jurnal Tek. Elektro dan Vokasional), vol. 5, no. 2, pp. 1-10, 2019

[13] Habibullah, J. Sardi, and Aswardi, "Solar powered portable electric stove for disaster impacted areas," Int. J. Sci. Technol. Res., vol. 8, no. 11, pp. 1305-1308, 2019.

\section{Biodata Penulis}

Juliem Zulfadli, lahir di Kota Padang, 2 Juli 1998. Sarjana Sains Terapan untuk Program Studi DIV Teknik Elektro Industri Jurusan Teknik Elektro Fakultas Teknik di Universitas Negeri Padang.

Habibullah, S.Pd, M.T, lahir di Kota Padang, 20 September 1982. Menyelesaikan S1 di Universitas Negeri Padang. Memperoleh gelar Magister di Universitas Indonesia. Sekarang menjadi dosen Teknik Elektro di Universitas Negeri Padang. 